\title{
Infrared spectroscopy of racemic and enantiomeric forms of atenolol
}

\author{
R.A. Esteves de Castro ${ }^{\text {, }}$, João Canotilho ${ }^{\text {b,* }}$, Rui M. Barbosa ${ }^{\text {b }}$, J. Simões Redinha ${ }^{a}$ \\ ${ }^{a}$ Chemistry Department, Rua Larga 3004-535, University of Coimbra, Portugal \\ ${ }^{\mathrm{b}}$ Faculty of Pharmacy, Rua do Norte 3000-295, University of Coimbra, Portugal
}

Received 12 June 2006; received in revised form 22 September 2006; accepted 5 October 2006

\begin{abstract}
The molecular structure of conformational isomorphs given by X-ray diffraction for racemic and enantiomeric atenolol were optimized at the $\mathrm{HF} / 6-31 \mathrm{G}^{*}$ level of theory and the infrared spectra of the structure were calculated. These spectra are used to characterize the differences between the various atenolol conformers.

The spectra of the $(R, S)$ - and $S$-atenolol solid forms were recorded and the bands corresponding to the functional groups identified with the aid of the calculated spectra, fitting analysis, temperature effect and H/D isotopic exchange. Particular attention was paid to the stretch vibration modes of the functional groups present in the atenolol.
\end{abstract}

(C) 2006 Elsevier B.V. All rights reserved.

Keywords: Atenolol; $\beta$-Blockers; Chiral drugs; IR spectroscopy; Conformational isomorphism

\section{Introduction}

Atenolol, $\quad 4-\left[2^{\prime}\right.$-hydroxy-3'-[(1-methylethyl)amino $]$ propoxy]-benzeneacetamide, (see Fig. 1 for structure and atom numbering), is a drug widely used in blood pressure control as a $\beta$-blocker [1-3]. The knowledge of the structure is therefore of utmost importance for understanding the physico-chemical behaviour and biological action of this compound.

In a previous study the crystal structure of the racemic and enantiomeric forms were determined by X-ray diffraction [4]. Infrared spectroscopy is now being used to gain a deeper insight into the structure. While in X-ray diffraction analysis the occurrence of hydrogen bonds is inferred from the molecular geometry and the relative positions of donor and acceptor atoms, the influence of the acceptor on the potential energy of the donor group can be shown by vibrational spectroscopy. Hydrogen bonding gives rise to displacement of the vibration frequency of the donor group relative to that observed for the respective vibrational mode in the free molecule. This makes infrared spectroscopy an excellent method for investigating hydrogen bonding. As the atenolol molecule contains several groups able to act as donor or acceptor, infrared spectroscopy can be very helpful in understanding the structure.

\footnotetext{
* Corresponding author. Tel.: +351 239859950; fax: +351 239827126.

E-mail address: jcano@ci.uc.pt (J. Canotilho).
}

In the work mentioned above it was shown that the crystallographic unit cell of these compounds contains different conformational forms. The aim of this work is therefore to characterize the solid structures and the conformational forms by vibrational spectroscopy.

\section{Experimental}

$(R, S)$-Atenolol supplied by Mikromol Gmbh (Luckenwalde, D), lot 13.00.02.01, as certified reference material $99.76 \mathrm{~mol} \%$ pure and $S$-(-)atenolol from Sigma-Aldrich labelled as $99 \%$ pure were used. Both products were tested by HPLC and no impurity was detected. The value of $[\alpha]_{\mathrm{D}}^{25}(\mathrm{C}=1$ in $1 \mathrm{~N} \mathrm{HCl})$ found for $S$-atenolol was $-16.2^{\circ}$.

The solid forms used in spectroscopy were prepared by slow evaporation of solutions of the compounds in ethanol:water $(20: 80, v / v)$, from which it was possible to grow single crystals suitable for X-ray diffraction. The solid used in spectroscopy was thus the same as that studied by X-ray diffraction.

Infrared spectra of the solid compounds were measured with a FTIR spectrophotometer (Thermo Nicolet, IR300, USA) using the $\mathrm{KBr}$ pellet technique. Thirty-two scans were run in each spectrum at a resolution of $1 \mathrm{~cm}^{-1}$. The spectra obtained were analysed using EZ Omnic 6.1 a software (Thermo Nicolet, USA).

Solutions of $(R, S)$ and $S$-atenolol in carbon tetrachloride were used to obtain spectra of the isolated molecules under study. 


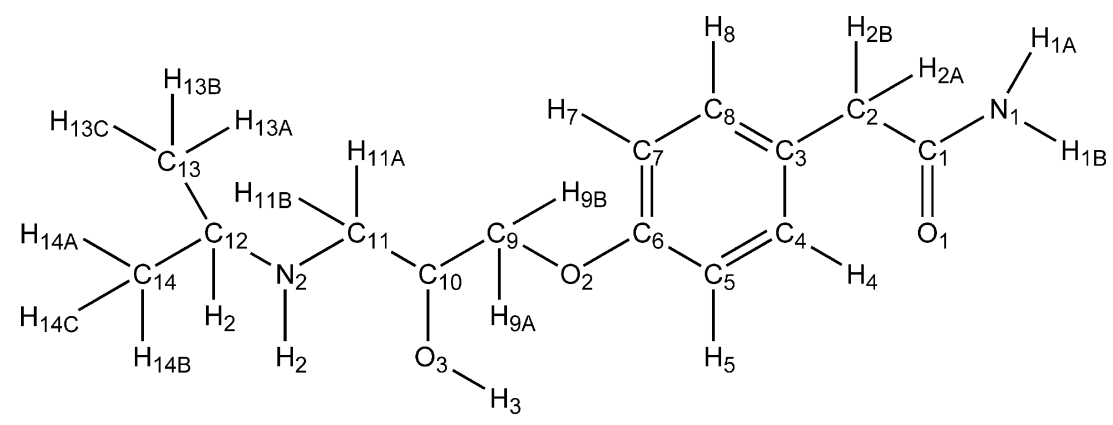

Fig. 1. Atenolol molecular structure and atom numbering.

The spectra were recorded in the $0.23-0.97 \mathrm{mM}$ concentration range using a $3.4 \mathrm{~mm}$ pathlength cell with sodium chloride windows.

Spectra were also recorded at temperatures between -170 and $150^{\circ} \mathrm{C}$ at $10^{\circ} \mathrm{C}$ intervals. A cell with sodium chloride windows and a temperature control device supplied by Graseby Specac were used to record these. To avoid water vapour condensation on the cell walls at low temperatures the cell compartment was kept under vacuum by a Edwards High Vacuum equipment consisting of a two-stage rotary pump in association with a turbomolecular pump. The temperature variation inside the cell was approximately $\pm 0.5^{\circ} \mathrm{C}$.

Spectra were also run on the deuterated compounds. Solid samples were maintained in equilibrium with deuterium oxide, 99.97\% percent-D at $60^{\circ} \mathrm{C}$ for $1 \mathrm{~h}$ under argon atmosphere. The liquid was then removed by evaporation at reduced pressure and a $\mathrm{KBr}$ pellet of the solid was prepared. According to the spectroscopic data about $20 \%$ of the solid is deuterated. No improvement was achieved by submitting the sample to longer equilibria times or successive equilibria with deuterium oxide.

\section{Calculated infrared spectra}

The $(R, S)$-atenolol crystallizes in the centrosymmetric $C / 2 c$ space group and $S$-atenolol in a non-centrossymetric $C 2$ space group. Single crystals of both compounds exhibit conformational isomorphism: two conformations $(R, S)_{1}$ and $(R, S)_{2}$ are observed for the $(R, S)$-atenolol and three, $S_{1}, S_{2}$ and $S_{3}$, for $S$ atenolol [4].

The hydrogen bond network established between the polar groups shown by X-ray diffraction data are given in Table 1 .

A reference spectrum needed to study of a molecule with the size of that atenolol can be obtained from the solute dissolved in an inert solvent or by computational calculation. The spectra of atenolol in carbon tetrachloride shown in Fig. 2 exhibit two

Table 1

Interatomic distances and angles related to intermolecular bonding

\begin{tabular}{llll}
\hline $\mathrm{D}-\mathrm{H} \cdots \mathrm{A}$ & $\mathrm{D} \cdots \mathrm{A}(\AA)$ & $\mathrm{H} \cdots \mathrm{A}(\AA)$ & $\mathrm{D}-\mathrm{H} \cdots \mathrm{A}\left({ }^{\circ}\right)$ \\
\hline $\mathrm{N}_{1}-\mathrm{H}_{1 \mathrm{~A}} \cdots \mathrm{O}_{1}$ & 2.909 & 2.05 & 174 \\
$\mathrm{~N}_{1}-\mathrm{H}_{1 \mathrm{~B}} \cdots \mathrm{O}_{1}$ & 2.864 & 2.05 & 158 \\
$\mathrm{O}_{3}-\mathrm{H}_{3} \cdots \mathrm{N}_{2}$ & 2.983 & 2.49 & 120 \\
$\mathrm{~N}_{2}-\mathrm{H}_{2} \cdots \mathrm{O}_{3}$ & 2.776 & 2.20 & 124 \\
\hline
\end{tabular}

From Ref. [4]. relatively intense broad bands at $\bar{\nu}_{\max }\left(3368\right.$ and $\left.3176 \mathrm{~cm}^{-1}\right)$ close to the anti-symmetric and symmetric stretch vibration of $\mathrm{N}_{1}-\left(\mathrm{H}_{1 \mathrm{~A}}, \mathrm{H}_{1 \mathrm{~B}}\right)$ group in the solid state as can be seen later in the text. The spectra indicate that in the range of concentration studied the atenolol molecules are self-associated. The absorption bands observed at $3616,3529 \mathrm{~cm}^{-1}$ and a shoulder at $3412 \mathrm{~cm}^{-1}$ may be ascribed to the stretch of $v\left(\mathrm{O}_{3}-\mathrm{H}_{3}\right), v_{\mathrm{a}}\left(\mathrm{N}_{1}-\mathrm{H}_{1 \mathrm{~A}}, \mathrm{H}_{1 \mathrm{~B}}\right)$ and $v_{\mathrm{s}}\left(\mathrm{N}_{1}-\mathrm{H}_{1 \mathrm{~A}}, \mathrm{H}_{1 \mathrm{~B}}\right)$ free groups (see Table 2). The molecular aggregation of the atenolol in nonpolar solvents, even at low concentration, does not allow the spectra of an isolated molecule to be obtained.

The flexibility of the atenolol molecule renders a conformational search impossible at a reasonable level of theory. To overcome this difficulty a reference spectrum was obtained by relaxation of the molecular structures provided by the X-ray diffractions. Fully optimized structures at the HF/6-31G* level of theory were obtained using the Gaussian 98 program package [5]. The structure so obtained allows comparison of the conformers present in the solid state and, given their similarity allows them to be used as reference to estimate the effects of the intermolecular forces.

Calculation using HF/4-31G* provides values for the acetamide fundamental vibrations, which are in agreement with the experimental values yielded by the matrix-isolation technique [6,7]. Despite the much higher flexibility of the atenolol

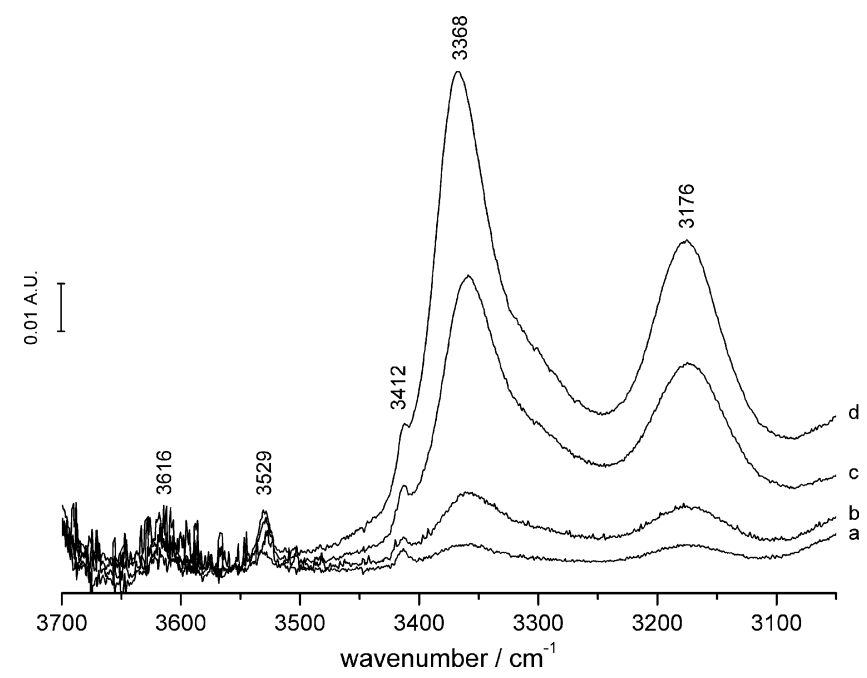

Fig. 2. Spectra of $(R, S)$-atenolol in carbon tetrachloride for different concentrations: (a) $0.23 \mathrm{mM}$; (b) $0.42 \mathrm{mM}$; (c) $0.77 \mathrm{mM}$; (d) $0.97 \mathrm{mM}$. 
Table 2

Calculated wavenumbers $\left(\mathrm{cm}^{-1}\right)$, calculated IR intensities $(I)$, and approximate description for $S_{1}$ conformation

\begin{tabular}{|c|c|c|c|c|}
\hline \multirow[t]{2}{*}{ Approximate description } & \multicolumn{2}{|l|}{ Atenolol } & \multicolumn{2}{|c|}{$\mathrm{H} / \mathrm{D}$ exchange } \\
\hline & $v\left(\mathrm{~cm}^{-1}\right)$ & $I_{\text {cal }}\left(\mathrm{km} \mathrm{mol}^{-1}\right)$ & $v\left(\mathrm{~cm}^{-1}\right)$ & $I_{\text {cal }}\left(\mathrm{km} \mathrm{mol}^{-1}\right)$ \\
\hline$v\left(\mathrm{O}_{3}-\mathrm{H}_{3}\right)$ & 3664 & 67 & 2668 & 43 \\
\hline$v_{\mathrm{a}}\left(\mathrm{N}_{1}-\left(\mathrm{H}_{1 \mathrm{~A}}, \mathrm{H}_{1 \mathrm{~B}}\right)\right)$ & 3550 & 85 & 2631 & 56 \\
\hline$v_{\mathrm{s}}\left(\mathrm{N}_{1}-\left(\mathrm{H}_{1 \mathrm{~A}}, \mathrm{H}_{1 \mathrm{~B}}\right)\right)$ & 3432 & 46 & 2480 & 46 \\
\hline$v\left(\mathrm{~N}_{2}-\mathrm{H}_{2}\right)$ & 3365 & 1 & 2462 & 2 \\
\hline$v\left(\mathrm{C}_{5}-\mathrm{H}_{5}\right)$ ring & 3044 & 12 & & \\
\hline$v\left(\mathrm{C}_{7}-\mathrm{H}_{7}\right)$ ring & 3028 & 10 & & \\
\hline$v\left(\mathrm{C}_{8}-\mathrm{H}_{8}\right)$ ring, $v\left(\mathrm{C}_{4}-\mathrm{H}_{4}\right)$ ring & 2998 & 33 & & \\
\hline$v_{\mathrm{a}}\left(\mathrm{C}_{9}-\left(\mathrm{H}_{9 \mathrm{~A}}, \mathrm{H}_{9 \mathrm{~B}}\right)\right)$ & 2949 & 35 & & \\
\hline$v_{\mathrm{a}}\left(\mathrm{C}_{14}-\left(\mathrm{H}_{14 \mathrm{~A}}, \mathrm{H}_{14 \mathrm{~B}}, \mathrm{H}_{14 \mathrm{C}}\right)\right)$ & 2933 & 50 & & \\
\hline$v_{\mathrm{a}}\left(\mathrm{C}_{2}-\left(\mathrm{H}_{2 \mathrm{~A}}, \mathrm{H}_{2 \mathrm{~B}}\right)\right)$ & 2930 & 7 & & \\
\hline$v_{\mathrm{a}}\left(\mathrm{C}_{13}-\left(\mathrm{H}_{13 \mathrm{~A}}, \mathrm{H}_{13 \mathrm{~B}}, \mathrm{H}_{13 \mathrm{C}}\right)\right)$ & 2923 & 43 & & \\
\hline$v_{\mathrm{a}}\left(\mathrm{C}_{13}-\left(\mathrm{H}_{13 \mathrm{~A}}, \mathrm{H}_{13 \mathrm{~B}}, \mathrm{H}_{13 \mathrm{C}}\right)\right), v_{\mathrm{a}}\left(\mathrm{C}_{14}-\left(\mathrm{H}_{14 \mathrm{~A}}, \mathrm{H}_{14 \mathrm{~B}}, \mathrm{H}_{14 \mathrm{C}}\right)\right)$, i.p. & 2915 & 125 & & \\
\hline$v_{\mathrm{a}}\left(\mathrm{C}_{11}-\left(\mathrm{H}_{11 \mathrm{~A}}, \mathrm{H}_{11 \mathrm{~B}}\right)\right)$ & 2904 & 35 & & \\
\hline$v_{a}\left(\mathrm{C}_{13}-\left(\mathrm{H}_{13 \mathrm{~A}}, \mathrm{H}_{13 \mathrm{~B}}, \mathrm{H}_{13 \mathrm{C}}\right)\right), v_{\mathrm{a}}\left(\mathrm{C}_{14}-\left(\mathrm{H}_{14 \mathrm{~A}}, \mathrm{H}_{14 \mathrm{~B}}, \mathrm{H}_{14 \mathrm{C}}\right)\right)$, o.p. & 2902 & 13 & & \\
\hline$v_{\mathrm{s}}\left(\mathrm{C}_{2}-\left(\mathrm{H}_{2 \mathrm{~A}}, \mathrm{H}_{2 \mathrm{~B}}\right)\right)$ & 2885 & 18 & & \\
\hline$v_{\mathrm{S}}\left(\mathrm{C}_{9}-\left(\mathrm{H}_{9 \mathrm{~A}}, \mathrm{H}_{9 \mathrm{~B}}\right)\right), v\left(\mathrm{C}_{10}-\mathrm{H}_{10}\right), v\left(\mathrm{C}_{12}-\mathrm{H}_{12}\right)$ & 2876 & 31 & & \\
\hline$v_{\mathrm{s}}\left(\mathrm{C}_{9}-\left(\mathrm{H}_{9 \mathrm{~A}}, \mathrm{H}_{9 \mathrm{~B}}\right)\right), v\left(\mathrm{C}_{12}-\mathrm{H}_{12}\right)$ & 2875 & 9 & & \\
\hline$v_{\mathrm{s}}\left(\mathrm{C}_{11}-\left(\mathrm{H}_{11 \mathrm{~A}}, \mathrm{H}_{11 \mathrm{~B}}\right)\right)$ & 2861 & 48 & & \\
\hline$v_{\mathrm{s}}\left(\mathrm{C}_{14}-\left(\mathrm{H}_{14 \mathrm{~A}}, \mathrm{H}_{14 \mathrm{~B}}, \mathrm{H}_{14 \mathrm{C}}\right)\right)$ & 2857 & 39 & & \\
\hline$v_{\mathrm{s}}\left(\mathrm{C}_{13}-\left(\mathrm{H}_{13 \mathrm{~A}}, \mathrm{H}_{13 \mathrm{~B}}, \mathrm{H}_{13 \mathrm{C}}\right)\right), v_{\mathrm{s}}\left(\mathrm{C}_{14}-\left(\mathrm{H}_{14 \mathrm{~A}}, \mathrm{H}_{14 \mathrm{~B}}, \mathrm{H}_{14 \mathrm{C}}\right)\right)$, o.p. $v\left(\mathrm{C}_{10}-\mathrm{H}_{10}\right)$ & 2851 & 24 & & \\
\hline$v\left(\mathrm{C}_{10}-\mathrm{H}_{10}\right), v_{\mathrm{s}}\left(\mathrm{C}_{13}-\left(\mathrm{H}_{13 \mathrm{~A}}, \mathrm{H}_{13 \mathrm{~B}}, \mathrm{H}_{13 \mathrm{C}}\right)\right)$ & 2850 & 21 & & \\
\hline$v\left(\mathrm{C}_{1}=\mathrm{O}_{1}\right)$ & 1755 & 549 & 1747 & 533 \\
\hline$v(\mathrm{C}=\mathrm{C})$ ring & 1628 & 92 & & \\
\hline$\delta\left(\mathrm{N}_{1}-\left(\mathrm{H}_{1 \mathrm{~A}}, \mathrm{H}_{1 \mathrm{~B}}\right)\right)$ & 1599 & 144 & & \\
\hline$v\left(\mathrm{C}_{1}-\mathrm{N}_{1}\right), \delta\left(\mathrm{N}_{1}-\left(\mathrm{D}_{\mathrm{A}}, \mathrm{D}_{\mathrm{B}}\right)\right)$ & & & 1366 & 267 \\
\hline$v(\mathrm{C}=\mathrm{C})$ ring & 1585 & 15 & & \\
\hline$v(\mathrm{C}-\mathrm{H})$ ring & 1516 & 166 & & \\
\hline$\delta\left(\mathrm{C}_{11}-\mathrm{N}_{2}-\mathrm{H}_{2}\right)$ & 1493 & 16 & & \\
\hline$\delta\left(\mathrm{C}_{9}-\left(\mathrm{H}_{9 \mathrm{~A}}, \mathrm{H}_{9 \mathrm{~B}}\right)\right)$ & 1486 & 66 & & \\
\hline$\delta\left(\mathrm{C}_{13}-\left(\mathrm{H}_{13 \mathrm{~A}}, \mathrm{H}_{13 \mathrm{~B}}, \mathrm{H}_{13 \mathrm{C}}\right)\right), \delta\left(\mathrm{C}_{14}-\left(\mathrm{H}_{14 \mathrm{~A}}, \mathrm{H}_{14 \mathrm{~B}}, \mathrm{H}_{14 \mathrm{C}}\right)\right)$, i.p. & 1476 & 5 & & \\
\hline$\delta\left(\mathrm{C}_{11}-\left(\mathrm{H}_{11 \mathrm{~A}}, \mathrm{H}_{11 \mathrm{~B}}\right)\right)$ & 1472 & 8 & & \\
\hline$\delta\left(\mathrm{C}_{13}-\left(\mathrm{H}_{13 \mathrm{~A}}, \mathrm{H}_{13 \mathrm{~B}}, \mathrm{H}_{13 \mathrm{C}}\right)\right), \delta\left(\mathrm{C}_{11}-\mathrm{N}_{2}-\mathrm{H}_{2}\right)$ & 1462 & 3 & & \\
\hline$\delta\left(\mathrm{C}_{2}-\left(\mathrm{H}_{2 \mathrm{~A}}, \mathrm{H}_{2 \mathrm{~B}}\right)\right)$ & 1438 & 4 & & \\
\hline $\mathrm{w}\left(\mathrm{C}_{9}-\left(\mathrm{H}_{9 \mathrm{~A}}, \mathrm{H}_{9 \mathrm{~B}}\right)\right), \delta\left(\mathrm{C}_{10}-\mathrm{O}_{3}-\mathrm{H}_{3}\right)$ & 1436 & 21 & 1131 & 57 \\
\hline $\mathrm{w}\left(\mathrm{C}_{9}-\left(\mathrm{H}_{9 \mathrm{~A}}, \mathrm{H}_{9 \mathrm{~B}}\right)\right), \delta\left(\mathrm{O}_{3}-\mathrm{C}_{10}-\mathrm{H}\right), \mathrm{w}\left(\mathrm{C}_{11}-\left(\mathrm{H}_{11 \mathrm{~A}}, \mathrm{H}_{11 \mathrm{~B}}\right)\right)$ & 1410 & 3 & & \\
\hline$\delta\left(\mathrm{C}_{13}-\left(\mathrm{H}_{13 \mathrm{~A}}, \mathrm{H}_{13 \mathrm{~B}}, \mathrm{H}_{13 \mathrm{C}}\right)\right), \delta\left(\mathrm{C}_{14}-\left(\mathrm{H}_{14 \mathrm{~A}}, \mathrm{H}_{14 \mathrm{~B}}, \mathrm{H}_{14 \mathrm{C}}\right)\right)$, i.p. & 1403 & 7 & & \\
\hline$\delta\left(\mathrm{C}_{13}-\left(\mathrm{H}_{13 \mathrm{~A}}, \mathrm{H}_{13 \mathrm{~B}}, \mathrm{H}_{13 \mathrm{C}}\right)\right), \delta\left(\mathrm{C}_{14}-\left(\mathrm{H}_{14 \mathrm{~A}}, \mathrm{H}_{14 \mathrm{~B}}, \mathrm{H}_{14 \mathrm{C}}\right)\right)$, o.p. & 1391 & 12 & & \\
\hline$\delta\left(\mathrm{O}_{3}-\mathrm{C}_{10}-\mathrm{H}_{10}\right)$ & 1350 & 18 & & \\
\hline $\mathrm{w}\left(\mathrm{C}_{9}-\left(\mathrm{H}_{9 \mathrm{~A}}, \mathrm{H}_{9 \mathrm{~B}}\right)\right), \delta\left(\mathrm{C}_{10}-\mathrm{C}_{11}-\mathrm{H}_{11}\right), \delta\left(\mathrm{C}_{9}-\mathrm{C}_{10}-\mathrm{H}_{10}\right)$ & 1344 & 51 & & \\
\hline$v\left(\mathrm{C}_{1}-\mathrm{N}_{1}\right), \delta\left(\mathrm{N} 1-\mathrm{H}_{1 \mathrm{~B}}\right)$ & 1330 & 165 & & \\
\hline$\delta\left(\mathrm{N}_{1}-\left(\mathrm{D}_{1 \mathrm{~A}}, \mathrm{D}_{1 \mathrm{~B}}\right)\right)$ & & & 1144 & 2 \\
\hline$\delta\left(\mathrm{C}_{14}-\mathrm{C}_{12}-\mathrm{H}_{12}\right)$ & 1326 & 13 & & \\
\hline $\mathrm{w}\left(\mathrm{C}_{2}-\left(\mathrm{H}_{2 \mathrm{~A}}, \mathrm{H}_{2 \mathrm{~B}}\right)\right), \delta(\mathrm{C}-\mathrm{H})$ ring & 1312 & 18 & & \\
\hline $\operatorname{tw}\left(\mathrm{C}_{9}-\left(\mathrm{H}_{9 \mathrm{~A}}, \mathrm{H}_{9 \mathrm{~A}}\right)\right), \operatorname{tw}\left(\mathrm{C}_{11}-\left(\mathrm{H}_{11 \mathrm{~A}}, \mathrm{H}_{11 \mathrm{~A}}\right)\right)$ & 1278 & 97 & & \\
\hline$v\left(\mathrm{C}_{6}-\mathrm{O}_{2}\right)$ & 1267 & 423 & & \\
\hline $\operatorname{tw}\left(\mathrm{C}_{9}-\left(\mathrm{H}_{9 \mathrm{~A}}, \mathrm{H}_{9 \mathrm{~B}}\right)\right)$ & 1240 & 25 & & \\
\hline$\delta\left(\mathrm{C}_{10}-\mathrm{O}_{3}-\mathrm{H}_{3}\right)$ & 1232 & 75 & 939 & 67 \\
\hline $\operatorname{tw}\left(\mathrm{C}_{2}-\left(\mathrm{H}_{2 \mathrm{~A}}, \mathrm{H}_{2 \mathrm{~B}}\right)\right)$ & 1209 & 17 & & \\
\hline$v\left(\mathbf{C}_{12}-\mathbf{N}_{2}\right)$ & 1167 & 40 & & \\
\hline$\delta(\mathrm{C}-\mathrm{C}-\mathrm{H})$ ring & 1165 & 25 & & \\
\hline $\operatorname{tw}\left(\mathrm{C}_{2}-\left(\mathrm{H}_{2 \mathrm{~A}}, \mathrm{H}_{2 \mathrm{~B}}\right)\right), \delta(\mathrm{C}-\mathrm{C}-\mathrm{H})$ ring o.o.p. & 1128 & 7 & & \\
\hline$v\left(\mathrm{C}_{10}-\mathrm{O}_{3}\right)$ & 1121 & 17 & & \\
\hline$v\left(\mathrm{C}_{11}-\mathrm{N}_{2}\right)$ & 1098 & 27 & & \\
\hline$v\left(\mathrm{C}_{9}-\mathrm{C}_{10}\right)$ & 1085 & 12 & & \\
\hline$\rho\left(\mathrm{N}_{1}-\left(\mathrm{H}_{1 \mathrm{~A}}, \mathrm{H}_{1 \mathrm{~B}}\right)\right)$ & 1082 & 6 & & \\
\hline$\rho\left(\mathrm{C}_{2}-\left(\mathrm{H}_{2 \mathrm{~A}}, \mathrm{H}_{2 \mathrm{~B}}\right)\right), \delta\left(\mathrm{C}_{1}-\mathrm{N}_{1}-\mathrm{D}_{1 \mathrm{~A}}\right)$ & & & 919 & 4 \\
\hline$\delta\left(\mathrm{C}_{1}-\mathrm{N}_{1}-\mathrm{D}_{1 \mathrm{~B}}\right)$ & & & 786 & 27 \\
\hline$\delta(\mathrm{C}=\mathrm{C})$ ring o.p. & 1073 & 14 & & \\
\hline$v\left(\mathrm{C}_{9}-\mathrm{O}_{2}\right)$ & 1052 & 83 & & \\
\hline$\delta\left(\mathrm{C}_{10}-\mathrm{O}_{3}-\mathrm{H}_{3}\right)$ & 1005 & 51 & 817 & 19 \\
\hline$\delta(\mathrm{C}=\mathrm{C})$ ring & 992 & 2 & & \\
\hline$\delta(\mathrm{C}-\mathrm{H})$ ring o.o.p. & 963 & 3 & & \\
\hline
\end{tabular}


Table 2 (Continued)

\begin{tabular}{lccc}
\hline Approximate description & Atenolol & H/D exchange \\
\cline { 2 - 3 } & $v\left(\mathrm{~cm}^{-1}\right)$ & $I_{\text {cal }}\left(\mathrm{km} \mathrm{mol}^{-1}\right)$ & 23 \\
\hline$\rho\left(\mathrm{C}_{10}-\mathrm{H}_{10}\right)$ & 937 & 8 & \\
$\rho\left(\mathrm{C} 2-\left(\mathrm{H}_{2 \mathrm{~A}}, \mathrm{H}_{2 \mathrm{~B}}\right)\right)$ & 922 & 41 \\
$\delta(\mathrm{C}-\mathrm{H})$ ring o.o.p. & 860 & 45 & \\
$\delta(\mathrm{C}-\mathrm{H})$ ring o.o.p. & 813 & 10 & 643 \\
$\delta(\mathrm{C}-\mathrm{H})$ ring o.o.p. & 776 & 67 & 46 \\
$\rho\left(\mathrm{N}_{2}-\mathrm{H}_{2}\right)$ & 725 & 25 & \\
$w\left(\mathrm{C}_{1}=\mathrm{O}_{1}\right)$ & 645 & 24 & \\
$\tau\left(\mathrm{N}_{1}-\left(\mathrm{H}_{1 \mathrm{~A}}, \mathrm{H}_{1 \mathrm{~B}}\right)\right)$ & 591 & 33 & \\
$\rho\left(\mathrm{C}_{1}=\mathrm{O}_{1}\right), \delta(\mathrm{C}-\mathrm{H})$ ring o.o.p. & 550 & 9 & \\
$\tau\left(\mathrm{C}_{1}-\mathrm{N}_{1}\right)$ & 487 & 9 & \\
$\tau\left(\mathrm{N}_{2}-\mathrm{H}_{2}\right)$ & 421 & 9 & \\
\hline
\end{tabular}

a: anti-symmetric; s: symmetric; $v$ : stretching; $\delta$ : in-plane deformation; w: wagging; $\rho$ : rocking; tw: twisting; $\tau$ : torsion; i.p.: in-phase; o.p.: out-of-phase; oop: out-of-plane deformation.

molecule, in the present work, a more robust basis set was used at a reasonable computational cost.

The vibrational frequencies were calculated for each structure at the same level of theory as that used in the optimization. The frequency correction factor was 0.8929 [8]. The spectra were simulated with the SYNSPEC program [9].

The calculated spectra corresponding to the various conformations are represented in Fig. 3. The band attribution was performed by GaussianView animation and the values of vibrational frequencies and intensities obtained for $S_{1}$ are given in Table 2. Bearing in mind the similarity of the spectra of the various conformations, for reasons of economy the band assignment was only tabled only for this conformer. Relevant features of the other conformations will be invoked as needed.

Theoretical spectra corresponding to the deuteration of $\mathrm{N}_{1}-\left(\mathrm{H}_{1 \mathrm{~A}}, \mathrm{H}_{1 \mathrm{~B}}\right), \mathrm{O}_{3}-\mathrm{H}_{3}$ and $\mathrm{N}_{2}-\mathrm{H}_{2}$, groups capable of $\mathrm{H} / \mathrm{D}$ isotopic exchange, were calculated at the same level as above. The absorption bands corresponding to these deuterated groups are inserted in Fig. 3 in dashed lines. The wavenumbers for $S_{1}$ conformer were included in Table 2.

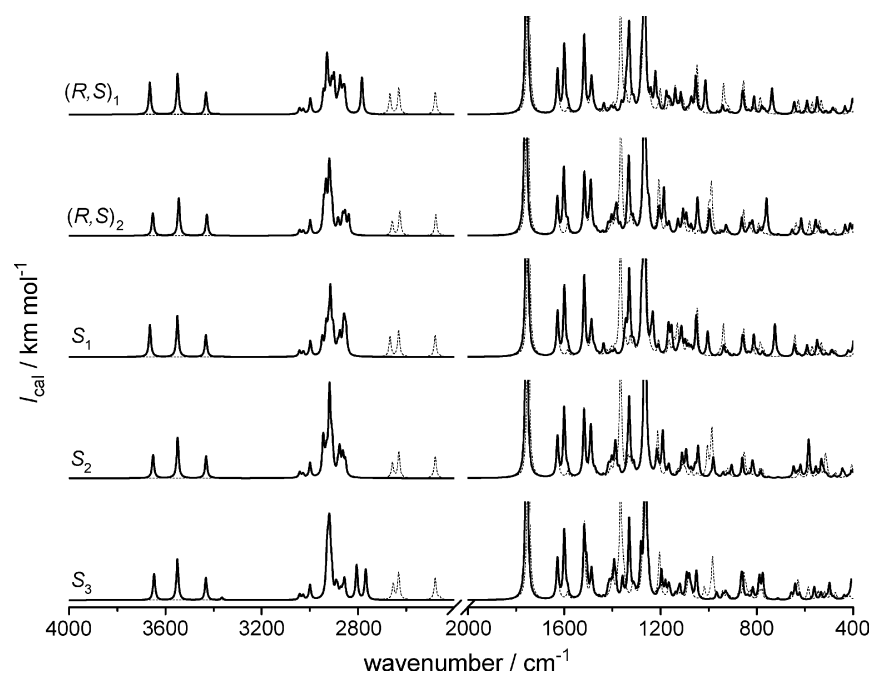

Fig. 3. Calculated infrared spectra for the conformers present in $S$ - and $(R, S)$ atenolol single crystals. The dashed lines represent the infrared spectra calculated for the deuterated conformers.
The values of the vibrational frequencies of several atenolol groups are in good agreement with those obtained experimentally for smaller molecules. For example the acetamide by argon matrix-isolation technique exhibits the following bands corresponding to the amide group [7]: $v_{\mathrm{a}}\left(\mathrm{NH}_{2}\right)=3552 \mathrm{~cm}^{-1}$, $v_{\mathrm{s}}\left(\mathrm{NH}_{2}\right)=3432 \mathrm{~cm}^{-1}, \quad v(\mathrm{C}=\mathrm{O})=1726 \mathrm{~cm}^{-1}, \quad \delta\left(\mathrm{NH}_{2}\right)=1585$ $\mathrm{cm}^{-1}, v(\mathrm{CN})=1315 \mathrm{~cm}^{-1}$. The secondary amine group gives rise to a variable weak band at $3340-3320 \mathrm{~cm}^{-1}$ [10]. The stretch frequency observed for the $\mathrm{OH}$ free group is slightly above the values tabled $[11,12]$ for this group $\left(3650-3600 \mathrm{~cm}^{-1}\right)$. Overestimated frequencies are commonly observed in this spectral region, using the conventional scale factor referred above $[13,14]$.

The comparison of the spectra for conformers shows that the vibration modes corresponding to the amide group do not vary from one conformer to another. However, the vibration modes of $\mathrm{O}_{3}-\mathrm{H}_{3}$ and $\mathrm{N}_{2}-\mathrm{H}_{2}$ exhibit significant differences in the frequency and intensity between conformers. The wavenumbers of the band maxima corresponding to these groups in $\mathrm{H}$ and $\mathrm{D}$ forms are presented in Table 3.

The wavenumber region between 3044 and $2768 \mathrm{~cm}^{-1}$ is occupied by $18 \mathrm{C}-\mathrm{H}$ stretch bands. The $3044-2949 \mathrm{~cm}^{-1}$ wavenumber interval corresponds to $\mathrm{C}-\mathrm{H}$ stretch vibrations modes of $\mathrm{C}_{4}$ to $\mathrm{C}_{9}$. In this interval the spectra are common to all conformers, in agreement with the information from the amide group spectra. However a diversity of bands is observed for conformers from $\mathrm{C}_{9}$ onwards. Some particularities should be pointed out in $v_{\mathrm{s}}\left(\mathrm{C}_{11}-\left(\mathrm{H}_{11 \mathrm{~A}}, \mathrm{H}_{11 \mathrm{~B}}\right)\right)=2806 \mathrm{~cm}^{-1}$ and $v\left(\mathrm{C}_{12}-\right.$ $\left.\mathrm{H}_{12}\right)=2768 \mathrm{~cm}^{-1} S_{3}$ bands and in $v\left(\mathrm{C}_{12}-\mathrm{H}_{12}\right)=2784 \mathrm{~cm}^{-1}$ $(R, S)_{1}$. These stretch frequencies are well below $\bar{v}_{\max }$ of the $\mathrm{C}-\mathrm{H}$ stretch vibrational mode of all the other groups and conformations. This is may be due to the influence of the single electron pair of oxygen and nitrogen on the $\mathrm{C}-\mathrm{H}$ stretch vibration, since it happens that this occurs in the groups in the neighbourhood of electronegative atoms.

The substitution of $\mathrm{H}$ with $\mathrm{D}$ shifts the bands of the functional groups towards lower frequencies. A small displacement in this direction is also observed for the $\mathrm{C}_{1}=\mathrm{O}_{1}$ stretching band. As this vibration mode is coupled with $\delta\left(\mathrm{N} 1-\left(\mathrm{H}_{1 \mathrm{~A}}, \mathrm{H}_{1 \mathrm{~B}}\right)\right)$ the uncoupling of the internal coordinates of 
Table 3

Band maxima in $\mathrm{cm}^{-1}$ of some fundamental vibration modes of $S$ - and $(R, S)$-atenolol conformers

\begin{tabular}{lllllllll}
\hline Conformer & $v\left(\mathrm{O}_{3}-\mathrm{H}_{3}\right)$ & $v\left(\mathrm{O}_{3}-\mathrm{D}_{3}\right)$ & $v\left(\mathrm{~N}_{2}-\mathrm{H}_{2}\right)$ & $v\left(\mathrm{~N}_{2}-\mathrm{D}_{2}\right)$ & $\delta\left(\mathrm{C}_{10}-\mathrm{O}_{3}-\mathrm{H}_{3}\right)$ & $\delta\left(\mathrm{C}_{10}-\mathrm{O}_{3}-\mathrm{D}_{3}\right)$ & $\delta\left(\mathrm{N}_{2}-\mathrm{H}_{2}\right)$ & $\delta\left(\mathrm{N}_{2}-\mathrm{D}_{2}\right)$ \\
\hline$(R, S)_{1}$ & $3665(66)$ & $2668(43)$ & $3382(1.2)$ & $2475(2.2)$ & $1222(79)$ & $938(61)$ & $737(53)$ & $630(13), 628(17)$ \\
$(R, S)_{2}$ & $3652(47)$ & $2658(30)$ & $3357(0.4)$ & $2456(1.1)$ & $1248(46)$ & $988(96)$ & $760(76)$ & $625(13), 617(17)$ \\
$S_{1}$ & $3664(67)$ & $2668(43)$ & $3365(1.1)$ & $2462(2.0)$ & $1232(75)$ & $939(67)$ & $725(67)$ & $643(46)$ \\
$S_{2}$ & $3651(48)$ & $2658(32)$ & $3404(0.5)$ & $2491(1.5)$ & $1216(49)$ & $986(97)$ & $585(78)$ & $516(46)$ \\
$S_{3}$ & $3647(55)$ & $2654(34)$ & $3365(5.6)$ & $2462(5.6)$ & $1196(56)$ & $984(84)$ & $776(51)$ & $630(36)$ \\
\hline
\end{tabular}

Calculated intensities in $\mathrm{km} \mathrm{mol}^{-1}$ are in parentheses.

both groups by deuteration shifts the band slightly towards lower frequencies.

The calculated spectra of the equilibrium conformational structures of the racemic and enantiomeric forms of atenolol allow the spectroscopic characterization of the conformers shown by X-ray diffraction. Further, they show that all conformers have the same structure from the molecular head to $\mathrm{C}_{9}$ and a diversity of structures in the remaining molecular moiety.

\section{Infrared spectra of $S$ - and $(R, S)$-atenolol in solid state}

Spectra of $S$ - and $(R, S)$-atenolol were recorded at different temperatures between -170 and $150^{\circ} \mathrm{C}$ at $10^{\circ} \mathrm{C}$ intervals. Fig. 4 gives the spectra of both compounds at 20 and $-170^{\circ} \mathrm{C}$. The racemic and enantiomeric forms show similar spectral patterns. A fall in temperature results in an increase in most bands and to a more detailed resolution.

The $3600-3000 \mathrm{~cm}^{-1}$ region was analysed by fitting Lorentzian curves to the spectra. Four bands are found at 3480 , 3358,3291 and $3174 \mathrm{~cm}^{-1}$ for $(R, S)$-atenolol at $20^{\circ} \mathrm{C}$.

The bands at $3358,3174 \mathrm{~cm}^{-1}$ can be firmly ascribed to the anti-symmetric and symmetric stretch vibration of the $\left(\mathrm{N}_{1}-\left(\mathrm{H}_{1 \mathrm{~A}}, \mathrm{H}_{1 \mathrm{~B}}\right)\right)$ group. These values are close to those given for this group in smaller amides [11]. The other two bands are more difficult to ascribe.

The deuteration of the compound displaces the spectra from $3480-3172 \mathrm{~cm}^{-1}$ to $2508-2327 \mathrm{~cm}^{-1}$, maintaining an identical pattern. The stronger bands 2508 and $2333 \mathrm{~cm}^{-1}$ for $(R, S)$-atenolol at $-170^{\circ} \mathrm{C}$ correspond to $\mathrm{N}_{1}-\left(\mathrm{D}_{1 \mathrm{~A}}, \mathrm{D}_{1 \mathrm{~B}}\right)$ and the rest should be ascribed to $\mathrm{O}_{3}-\mathrm{D}_{3}\left(2478 \mathrm{~cm}^{-1}\right)$ and $\mathrm{N}_{2}-\mathrm{D}_{2}$

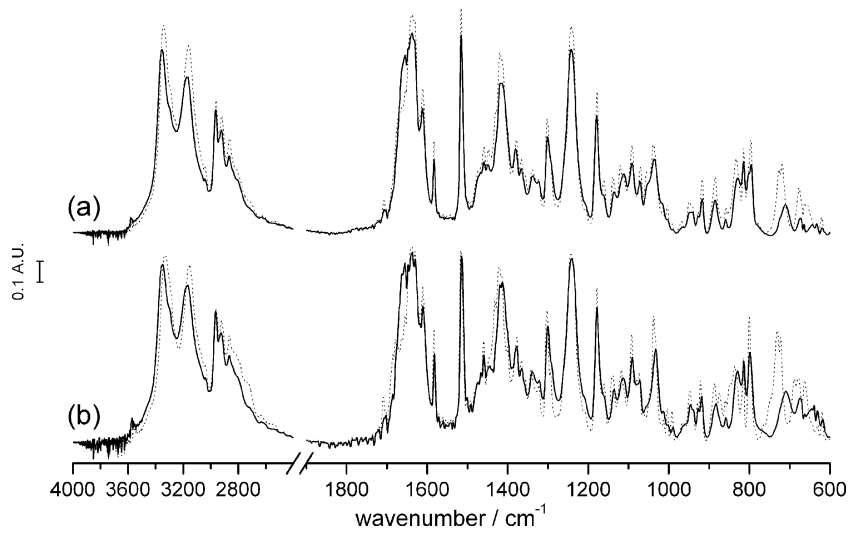

Fig. 4. Effect of temperature on the infrared spectra of: (a) $(R, S)$-atenolol and (b) $S$-atenolol. Solid line $20^{\circ} \mathrm{C}$, dotted line $-170^{\circ} \mathrm{C}$.

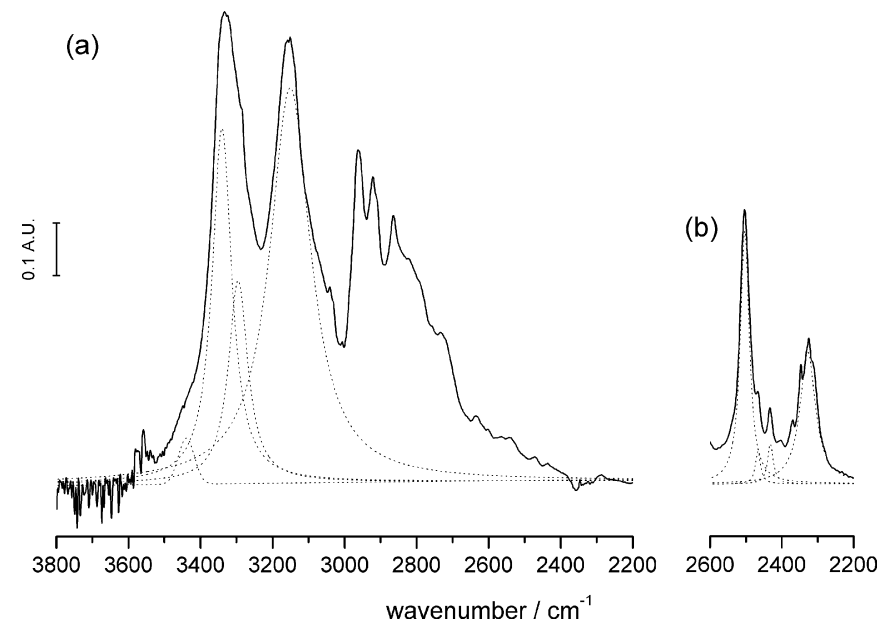

Fig. 5. Deuteration effect: (a) $S$-atenolol at $-170^{\circ} \mathrm{C}$; (b) spectra resulting from deuteration.

$\left(2433 \mathrm{~cm}^{-1}\right)$. This discrimination is based on the relative isotopic shift shown by the groups in the theoretical spectra (Table 2 and Fig. 3). The hydroxyl isotopic shift is more pronounced than that observed for the remaining groups thus a slightly different band maxima ordering arise. The overlap of $\mathrm{CO}_{2}$ stretch with the $2333 \mathrm{~cm}^{-1}$ band gives rise to a rather irregular profile (Fig. 5).

The deuteration should not affect the $\mathrm{C}-\mathrm{H}$ stretch region because this group does not participate in H/D equilibrium. However, a decrease in the intensity of the spectra is observed at some frequencies in this region, by deuteration, as shown in Fig. 6. Overtones or combination bands of nitrogen groups overlap the $\mathrm{C}-\mathrm{H}$ stretch vibration of some methylene groups. Indeed, the substitution the hydrogen by deuterium causes the disappearance of non-fundamental vibration modes at those frequencies, and consequently a decrease in the intensity. It is observed that the intensity of $2965 \mathrm{~cm}^{-1}$ band does not vary by deuteration, and for this reason it was used as a reference to scale the spectra obtained for the compounds before and after deuteration. Three non-fundamental vibration modes at $\bar{v}_{\max }=2920,2860$ and $2810 \mathrm{~cm}^{-1}$ are exhibited by atenolol.

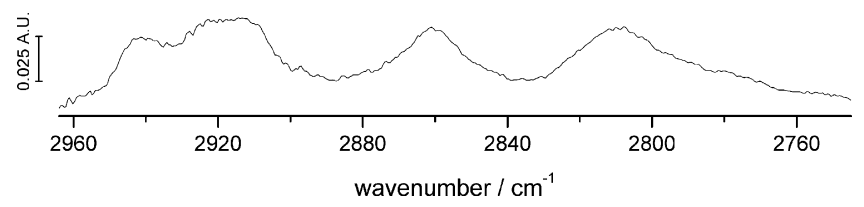

Fig. 6. Difference between the vibration intensity of $(R, S)$-atenolol spectra at $-170{ }^{\circ} \mathrm{C}$ before and after deuteration in the $\mathrm{C}-\mathrm{H}$ stretch vibration region. 

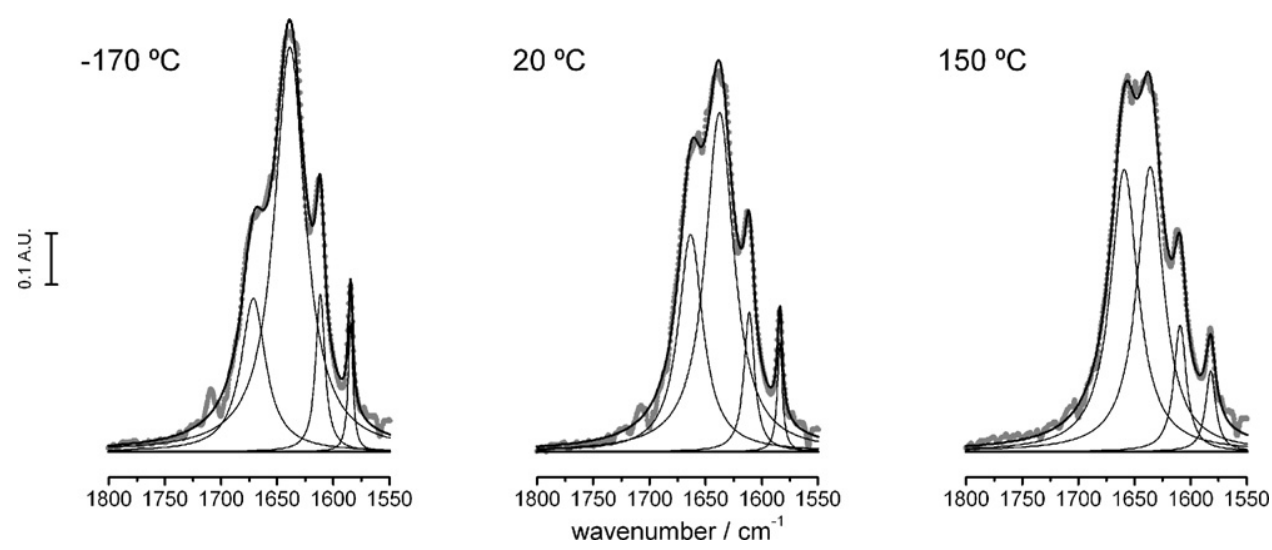

Fig. 7. Effect of temperature on the infrared spectra of solid $(R, S)$-atenolol between 1800 and $1550 \mathrm{~cm}^{-1}$.

Likewise, $N$-methylacetamide presents non-fundamental vibration bands at $2900-2650 \mathrm{~cm}^{-1}$ interpreted as Fermi resonances with the overtone and combination modes of amide bands [15].

An important band of the atenolol is that corresponding to $\mathrm{C}_{1}=\mathrm{O}_{1}$ stretch vibration, because it is intense and very sensitive to structure features. As a characteristic amide band is often called amide I and has been the object of much attention, both in small amides [16] and in polymeric compounds [17,18]. In spite of this, a detailed interpretation of amide I spectra is still a matter of controversy [16].

Lorentzian curve fitting in the spectra of $(R, S)$-atenolol at different temperatures in $1800-1550 \mathrm{~cm}^{-1}$ provides evidence for the existence of four component bands, as shown in Fig. 7. Characteristic parameters for the component bands are given in Table 4. The 1585 and $1612 \mathrm{~cm}^{-1}$ bands correspond to the $\mathrm{C}=\mathrm{C}$ ring stretch vibrations, as can be seen from Table 2 . The spectra of betaxolol, another $\beta$-blocker with a similar structure

Table 4

Peak fit analysis of $(R, S)$-atenolol in $1800-1550 \mathrm{~cm}^{-1}$ region at $-170,20$ and $150^{\circ} \mathrm{C}$

\begin{tabular}{cccc}
\hline $\bar{v}_{\max }\left(\mathrm{cm}^{-1}\right)$ & $\Delta \bar{\nu}_{1 / 2}\left(\mathrm{~cm}^{-1}\right)$ & $h$ (a.u.) & $I(\%)$ \\
\hline$-170{ }^{\circ} \mathrm{C}$ & & & \\
1671 & 27 & 0.31 & 22 \\
1639 & 32 & 0.78 & 67 \\
1612 & 10 & 0.31 & 9 \\
1585 & 5 & 0.25 & 3 \\
& & & \\
$20^{\circ} \mathrm{C}$ & & & \\
1663 & 27 & 0.43 & 32 \\
1637 & 30 & 0.66 & 54 \\
1611 & 12 & 0.28 & 9 \\
1584 & 6 & 0.21 & 3 \\
& & & \\
$150{ }^{\circ} \mathrm{C}$ & & & 44 \\
1659 & 28 & 0.56 & 43 \\
1636 & 28 & 0.55 & 4 \\
1608 & 14 & 0.25 & 4 \\
1582 & 8 & 0.16 & \\
\hline
\end{tabular}

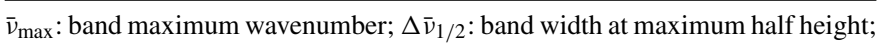
$h$ : band maximum height; $I$ : relative intensity (area percent under the bands of the respective spectral region). to atenolol but without amide groups, exhibits these two bands [19]. Thus only 1671 and $1639 \mathrm{~cm}^{-1}$ are components of amide I.

It has been observed that hydrogen bonding gives rise to a red shift of $v(\mathrm{C}=\mathrm{O})$ and a blue shift of $\delta\left(\mathrm{NH}_{2}\right)$ [16]. A partial overlapping of the bands corresponding to these vibration modes thus occurs, making the spectra appear as a doublet [11]. This is apparently the case in the system under study. However, a more detailed analysis of the data is important from the structure point of view.

As the temperature rises, the intensity of the higher frequency band increases at the same rate as the intensity of the lower frequency band decreases. At $-170^{\circ} \mathrm{C}$ the intensity ratio of both bands is $1: 3$ and at $150^{\circ} \mathrm{C}$, a temperature near melting point, the ratio is approximately $1: 1$. This behaviour indicates that at a higher temperature the carbonyl group is involved in two similar energy structures which are distinguished by the stretch vibration mode. Also worthy of note are the differences given by X-ray diffraction for the parameters related to the hydrogen bonds $\mathrm{N}_{1}-\mathrm{H}_{1 \mathrm{~A}} \cdots \mathrm{O} 1$ and $\mathrm{N}_{1}-\mathrm{H}_{1 \mathrm{~B}} \cdots \mathrm{O}_{1}$. The differences found for the bonds involving $\mathrm{H}_{1 \mathrm{~A}}$ or $\mathrm{H}_{1 \mathrm{~B}}$ can influence the $\mathrm{C}_{1}=\mathrm{O}_{1}$ stretch vibration. As the temperature decreases molecular freedom decreases too, and the structure tends towards that of lower energy states.

The position of the $\delta\left(\mathrm{N}_{1}-\mathrm{H}_{1 \mathrm{~A}}\right)$ band is manifested by deuteration. In Fig. 8 shows the spectra of $(R, S)$-atenolol at $-170^{\circ} \mathrm{C}$ before and after being deuterated. The spectra were normalized by a factor determined from the $2965 \mathrm{~cm}^{-1} \mathrm{C}-\mathrm{H}$ stretch vibration band, as explained above.

A fall in the intensity by deuteration occurs in the wavenumber $1684-1651 \mathrm{~cm}^{-1}$ interval, that is, practically coincident with the higher frequency $\mathrm{C}_{1}=\mathrm{O}_{1}$. A new band at $1434 \mathrm{~cm}^{-1}$, partially overlapping that at $1419 \mathrm{~cm}^{-1}$, then appears.

To estimate the enthalpy of the hydrogen bond involving $\mathrm{O}_{3}-\mathrm{H}_{3}$ and $\mathrm{N}_{2}-\mathrm{H}_{2}$ donors the mean values obtained for the wavenumbers of these free groups for all conformers, and the mean of the values found for $(R, S)$ and $S$-atenolol in the solid state at $20^{\circ} \mathrm{C}$, were considered. For the hydrogen bond established by the amide group, the shift of the symmetric stretch vibration of $\mathrm{N}_{1}-\left(\mathrm{H}_{1 \mathrm{~A}}, \mathrm{H}_{1 \mathrm{~B}}\right)$ was taken. The enthalpies associated with the hydrogen bonds given in Table 5 are calculated using the equation proposed by Iogansen [12]. 
Table 5

Enthalpy of intermolecular hydrogen bonds calculated from the absorption frequency shift

\begin{tabular}{llllr}
\hline Hydrogen bond & Vibration mode & $\bar{v}_{\max }$ free group $\left(\mathrm{cm}^{-1}\right)$ & $\bar{v}_{\max }$ solid $\left(\mathrm{cm}^{-1}\right)$ & $\Delta v\left(\mathrm{~cm}^{-1}\right)$ \\
\hline $\mathrm{O}_{3}-\mathrm{H}_{3} \cdots \mathrm{N}_{2}$ & $v\left(\mathrm{O}_{3}-\mathrm{H}_{3}\right)$ & 3656 & 3472 & 184 \\
$\mathrm{~N}_{2}-\mathrm{H}_{2} \cdots \mathrm{O}_{3}$ & $\nu\left(\mathrm{N}_{2}-\mathrm{H}_{2}\right)$ & 3375 & 3293 & 82 \\
$\mathrm{~N}_{1}-\left(\mathrm{H}_{1 \mathrm{~A}}, \mathrm{H}_{1 \mathrm{~B}}\right) \cdots \mathrm{O}_{1}$ & $v_{\mathrm{s}}\left(\mathrm{N}_{1}-\mathrm{H}_{1 \mathrm{~A}}, \mathrm{H}_{1 \mathrm{~B}}\right)$ & 3431 & 3173 & 9 \\
\hline
\end{tabular}

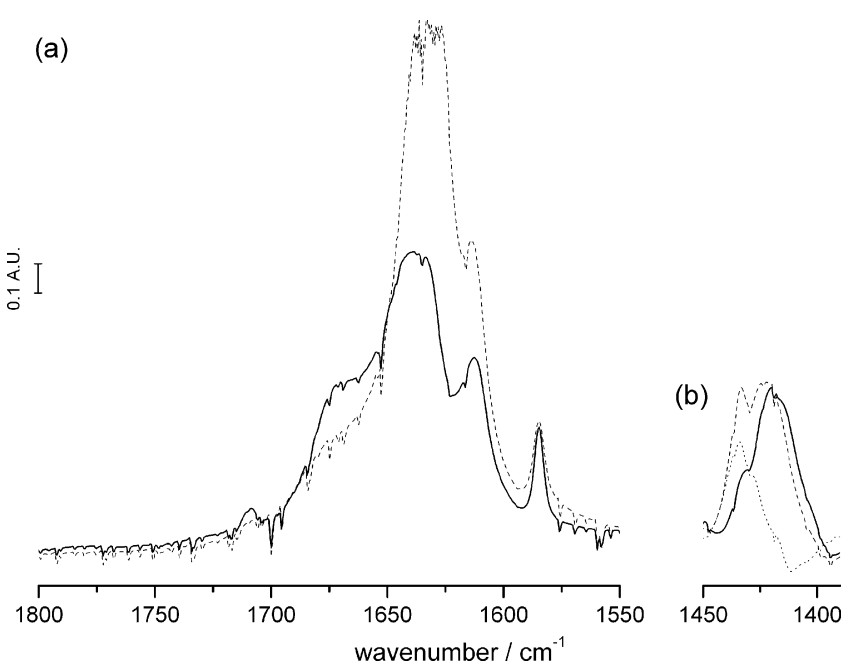

Fig. 8. Infrared spectra of $(R, S)$-atenolol at $-170^{\circ} \mathrm{C}$ (solid line), $(R, S)$-atenolol deuterated at $-170^{\circ} \mathrm{C}$ (dashed line); dotted line in (b) is the difference between the two overlapping curves.

The values presented in Table 5 are of the same order of magnitude as those that can be calculated by other equations, such as that devised by Stolov [20].

\section{Conclusions}

The infrared spectra calculated from X-ray diffraction data provides valuable structure information about the conformers present in $(R, S)$ - and $S$-atenolol. Significant spectral differences between conformers were found for the groups of the first molecule moiety (amide and $\mathrm{C}-\mathrm{H}$ up to $\mathrm{C}_{9}$ ), whereas, in contrast, the spectra from $\mathrm{C}_{9}$ on differ from one conformer to another. This means that all conformers exhibit a common structure from the amide group to $\mathrm{C}_{9}$ and different structure backbones from this carbon atom to the molecule end.

The analysis of the spectra of solid atenolol in the $3700-1550 \mathrm{~cm}^{-1}$ interval provides evidence for important structural features, in particular on the hydrogen bond network of the compound in solid state.

The stretch vibration of the carbonyl group provides detailed information on the intermolecular hydrogen bonds of $\mathrm{N}_{1}-\left(\mathrm{H}_{1 \mathrm{~A}}, \mathrm{H}_{1 \mathrm{~B}}\right)$ with neighbour molecules.

The $\mathrm{C}_{1}=\mathrm{O}_{1}$ stretch gives a doublet in both the racemic and the enantiomeric form. The conversion of the one of the com- ponents' bands into another takes place under temperature variation.

\section{Acknowledgement}

R.A.E.C. thanks the PRODEP III Project 05.03/C/00206.012/ 03 for financial support.

\section{References}

[1] L.S. Goodman, A. Gilman, Goodman \& Gilman's the Pharmacological Basis of Therapeutics, 11th ed., McGraw-Hill, New York, 2006.

[2] L.H. Lindholm, B. Carlberg, O. Samuelsson, Lancet 366 (2005) 1545.

[3] Guidelines_Committee, J. Hypertension 21 (2003) 1011.

[4] R.A.E. Castro, J. Canotilho, R.M. Barbosa, M.R. Silva, A.M. Beja, J.A. Paixão, J.S. Redinha, Cryst. Growth Des., submitted for publication.

[5] M.J. Frisch, G.W. Trucks, H.B. Schlegel, G.E. Scuseria, M.A. Robb, J.R. Cheeseman, V.G. Zakrzewski, J.A. Montgomery, R.E. Stratmann, J.C. Burant, S. Dapprich, J.M. Millam, A.D. Daniels, K.N. Kudin, M.C. Strain, O. Farkas, J. Tomasi, V. Barone, M. Cossi, R. Cammi, B. Mennucci, C. Pomelli, C. Adamo, S. Clifford, J. Ochterski, G.A. Petersson, P.Y. Ayala, Q. Cui, K. Morokuma, D.K. Malick, A.D. Rabuck, K. Raghavachari, J.B. Foresman, J. Cioslowski, J.V. Ortiz, A.G. Baboul, B.B. Stefanov, G. Liu, A. Liashenko, P. Piskorz, I. Komaromi, R. Gomperts, R.L. Martin, D.J. Fox, T. Keith, M.A. Al-Laham, C.Y. Peng, A. Nanayakkara, M. Challacombe, P.M.W. Gill, B. Johnson, W. Chen, M.W. Wong, J.L. Andres, C. Gonzalez, M. Head-Gordon, E.S. Replogle, J.A. Pople, GAUSSIAN 98 Revision A. 9, Gaussian, Inc., Pittsburgh, PA, 1998.

[6] Y. Hase, Spectrochim. Acta Part a: Mol. Biomol. Spectrosc. 51 (1995) 2561.

[7] R. Knudsen, O. Sala, Y. Hase, J. Mol. Struct. 321 (1994) 187.

[8] D.J. Defrees, A.D. McLean, J. Chem. Phys. 82 (1985) 333.

[9] K.K. Irikura, SYNSPEC, Physical and Chemical Properties Division National Institute of Standards and Technology, Gaithersburg, MD, 1995.

[10] H. Wolff, G. Gamer, Spectrochim. Acta Part a: Mol. Spectrosc. A 28 (1972) 2121.

[11] D.L. Pavia, G.M. Lampman, G.S. Kriz, Introduction to Spectroscopy, 3rd ed., Harcourt College, Orlando, USA, 2001.

[12] A.V. Iogansen, Spectrochim. Acta Part A 55 (1999) 1585.

[13] J. Canotilho, R.A.E. de Castro, M. Helena, S.F. Teixeira, M.L.P. Leitao, J.S. Redinha, Spectrochim. Acta Part A 64 (2006) 279.

[14] Y.A. Abramov, A. Volkov, G. Wu, P. Coppens, J. Phys. Chem. B 104 (2000) 2183.

[15] J. Edler, P. Hamm, Phys. Rev. B 69 (2004) 214301.

[16] W.A. Herrebout, K. Clou, H.O. Desseyn, J. Phys. Chem. A 105 (2001) 4865.

[17] B. Zhu, Y. He, N. Yoshie, N. Asakawa, Y. Inoue, Macromolecules 37 (2004) 3257.

[18] A.M. Heintz, R.L. McKiernan, S.P. Gido, J. Penelle, S.L. Hsu, Macromolecules 35 (2002) 3117.

[19] Data obtained by the authors to be published elsewhere.

[20] A.A. Stolov, M.D. Borisover, B.N. Solomonov, J. Phys. Org. Chem. 9 (1996) 241. 